OPEN ACCESS

Edited by: Alessandro Russo, A.O. Papardo, Italy

Reviewed by: Frank James Ward, University of Aberdeen,

United Kingdom

Donglei Zhang,

Chinese Academy of Medical Sciences and Peking Union Medical

College, China

*Correspondence:

LeJie Cao

sycaolejie@163.com

Specialty section:

This article was submitted to

Cancer Immunity

and Immunotherapy,

a section of the journal

Frontiers in Immunology

Received: 06 October 2021 Accepted: 22 November 2021 Published: 09 December 2021

Citation:

Xie W, Hu N and Cao L (2021) Immune Thrombocytopenia Induced by Immune Checkpoint Inhibitors in Lung Cancer: Case

Report and Literature Review.

Front. Immunol. 12:790051. doi: 10.3389/fimmu.2021.790051

\section{Immune Thrombocytopenia Induced by Immune Checkpoint Inhibitrs in Lung Cancer: Case Report and Literature Review}

\author{
Wang Xie, NaNa Hu and LeJie Cao* \\ Department of Pulmonary and Critical Care Medicine, The First Affiliated Hospital of University of Science and Technology \\ of China, Division of Life Sciences and Medicine, University of Science and Technology of China, Hefei, China
}

Immune checkpoint inhibitors (ICls), including antibodies targeting programmed cell death protein-1 (PD-1) and programmed cell death ligand-1 (PD-L1), are being extensively used on advanced human malignancies therapy. The treatment with ICls have acquired durable tumor inhibition and changed the treatment landscape in lung cancer. Immune-related adverse events including pneumonitis and thyroiditis have been well described, but less frequent events, such as ICls-induced thrombocytopenia, are now emerging and may sometimes be severe or fatal. Since early detection and prompt intervention are crucial to prevent fatal consequences, it is of outmost importance that medical staff is aware of these potential toxicities and learn to recognize and treat them adequately. This review focuses on the epidemiology, clinical presentation, mechanisms, and clinical management of ICls-induced thrombocytopenia in patients with lung cancer. We also present a patient with advanced lung adenocarcinoma who received the PD-L1 inhibitor atezolizumab and eventually developed severe thrombocytopenia. The case indirectly suggests that cytokine changes might contribute to immune dysregulation in ICls-induced thrombocytopenia.

Keywords: programmed cell death 1 inhibitor, immune thrombocytopenia, immune checkpoint inhibitor, atezolizumab, immune-related adverse event (irAE)

\section{INTRODUCTION}

Immune checkpoint inhibitors (ICIs) lead to a significant improvement of overall survival (OS) in advanced non-small-cell lung cancer (NSCLC), and $8 \%$ of responded patients have achieved long-term survival (1). Atezolizumab, a humanized monoclonal antibody binding to programmed cell deathligand 1, is currently approved for use against extensive small-cell lung cancer (SCLC) and has few treatment discontinuation rates due to adverse events (AEs) (2). Similar to other ICIs, atezolizumab can cause immune-related adverse events (irAEs), including endocrine, pneumonitis, hepatitis, thyroiditis, nephritis, and colitis. With the growing application of ICIs, the rate of hematologic toxicity has been observed in many cases $(3,4)$. In particular, ICIs-induced thrombocytopenia has been reported in a few cases with lung cancer (5). Herein, we reported a case of atezolizumab-induced immune thrombocytopenia and discussed the clinical management. We also review the epidemiology, clinical presentation, and prognosis of immune thrombocytopenia caused by ICIs in patients with advanced lung cancer. 


\section{CASE PRESENTATIONS}

In a case report, a 76-year-old male with stage IV adenocarcinoma (cT2bN2M1b) without targetable genomic alterations, such as epidermal growth factor receptor (EGFR), anaplastic lymphoma kinase (ALK), rearranged c-ros oncogene 1 (ROS1), was diagnosed by right abdominal muscle surgical resection. Chest computed tomography (CT) revealed the tumor shadow in the right lower lobe of the lung, and it also demonstrated multiple swollen lymph nodes in the mediastinum (Figure 1). ${ }^{18} \mathrm{~F}$-fluorodeoxyglucose positron emission tomography-computed tomography (PET/ CT) showed multiple 18F-fluorodeoxyglucose (18F-FDG) uptake in the right abdominal muscle, L4, and right iliac bone. Baseline data showed that blood tests were normal, and Eastern Cooperative Oncology Group (ECOG) score was 1. The patient was recruited into a clinical study (IMpower 132) and received 6 cycles of carboplatin, pemetrexed, and atezolizumab (every 3 weeks) treatment. Then the patient showed a partial response indicated by a CT scan, and no severe toxicities were observed in February 2019, followed by 36 cycles of maintenance therapy with pemetrexed and atezolizumab. During the treatment, blood tests were performed every 3 weeks and no hematological abnormality was found. In November 2020, the patient developed thrombocytopenia (platelet level: $91 \times 10^{3} / \mathrm{ul}$ ) with normal hemoglobin and normal white cell counts and received the interleukin-11(IL-11) therapy to enhance the proliferation of megalokaryocytes for 2 weeks. Unfortunately, his platelet count slightly declined, and no autoimmune or coagulation disorders were displayed. As a result, the diagnosis was presumed as ICIsinduced thrombocytopenia, and he was treated with prednisone for 2 weeks $(0.5 \mathrm{mg} / \mathrm{kg})$. However, his thrombocytopenia became worse with a sudden decrease in platelet level to $35 \times 10^{3} / \mathrm{ul}$. Thus, the pemetrexed and atezolizumab were discontinued. A bone marrow biopsy examination demonstrated no obvious morphological abnormalities, phagocytosis, or malignant invasion happened to this patient. Furthermore, antinuclear antibodies and other laboratory tests were negative, but antiphospholipid and antiplatelet antibodies were abnormal. After excluding chemotherapy, infection, pseudothrombocytopenia, or other druginduced thrombocytopenia, atezolizumab-induced immune thrombocytopenia was finally diagnosed. Therefore, we gave him a high-dose steroid for 6 consecutive days and recombinant human thrombopoietin (TPO). However, his platelet count showed no improvement and stayed at the level of $23 \times 10^{3} / \mathrm{ul}$. He then received four times of platelet transfusions, mycophenolate mofetil, and infusion of intravenous immunoglobulin (IVIG), but his platelets did not recover. The lowest platelet level was recorded on February 20,2021 , with a level of $20 \times 10^{3} / \mathrm{ul}$. Interestingly, the level of serum interleukin-6 (IL-6) was significantly increased compared to the normal range, and we prescribed him an IL-6 receptor antagonist, tocilizumab, at $400 \mathrm{mg}$ in addition to mycophenolate mofetil. Seven days later, his platelet counts started to increase and reach the normal range ( 100 to $300 \times 10^{3} / \mathrm{ul}$ ) by 1 week (Figure 2$)$. The patient stayed a partial response to the treatment during atezolizumab therapy interruptions.

\section{EPIDEMIOLOGY OF ICIS-INDUCED THROMBOCYTOPENIA}

ICIs-induced thrombocytopenia in patients with lung cancer have been reported in many studies (Table 1), and thrombocytopenia has been demonstrated to be one of the most important hematological toxicity of hematological irAEs (21). There is
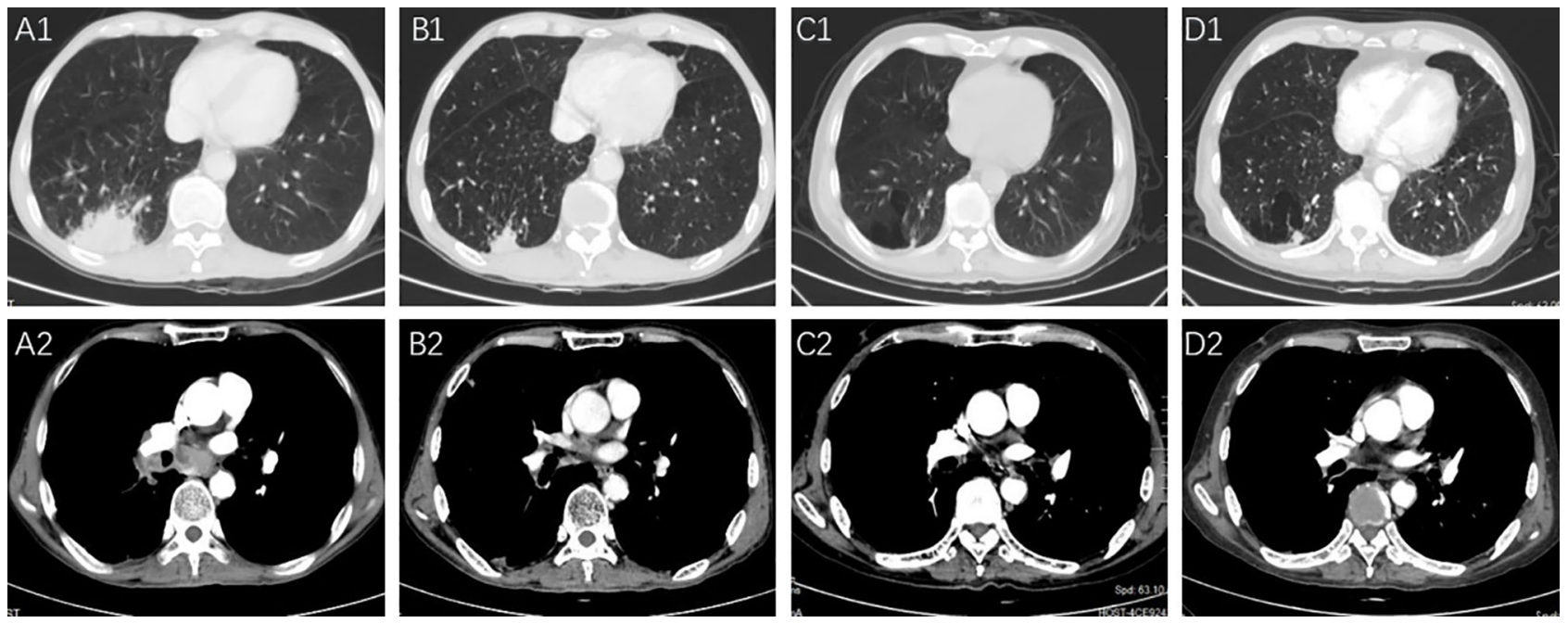

FIGURE 1 | The pulmonary lesions and lymph node metastases before and after the PD-L1 treatment. (A1, A2) Right lower pulmonary lesions and swollen lymph nodes were revealed in the CT images before starting the chemotherapy in May 2018. (B1, B2) Partial response of the lesions in the right lower lobe and swollen lymph nodes was shown after 6 cycles of chemotherapy and atezolizumab treatment in August 2018; (C1, C2) the lesions showed continuous partial response after 36 cycles of pemetrexed and atezolizumab; (D1, D2) the lesions indicated a decreased size in March 2021. 


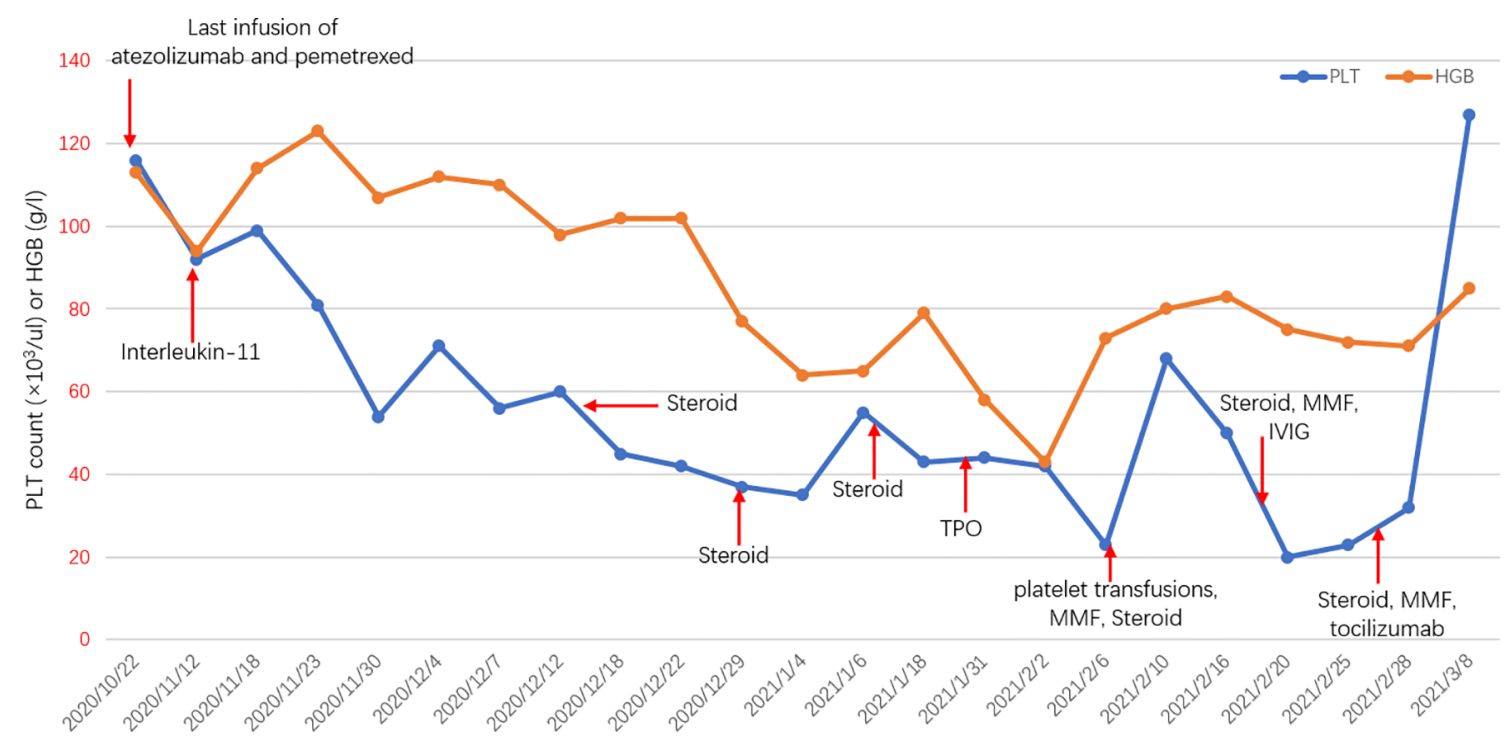

FIGURE 2 | Longitudinal changes in PLT count or HGB over time. PLT, platelet; HGB, hemoglobin; MMF, mycophenolate mofetil; IVIG, intravenous immunoglobulin; TPO, thrombopoietin.

usually a favorable prognosis in patients with thrombocytopenia. However, it is difficult to separate from chemotherapy-induced thrombocytopenia; therefore, the absolute incidence of ICIsinduced thrombocytopenia cannot be calculated. In one retrospective study, the incidence of ICIs-induced thrombocytopenia was less than $1 \%$ on ICIs (22), but in the observation study, the frequency of immune thrombocytopenia seems to be relatively high, accounting for 25-29\% of hematological irAEs $(23,24)$. Besides, combination therapy was also associated with significantly higher risks of immune thrombocytopenia (5).

Table 1 summarizes the reported cases of immune thrombocytopenia during ICIs therapy in patients with lung cancer. Most studies revealed that the onset of immune thrombocytopenia usually occurred within the first 12 weeks of ICIs initiation, but it can be at any time, even after cessation of treatment (25). Here, we reported the first case of one patient with lung cancer who developed late-onset immune thrombocytopenia during atezolizumab therapy. Similar to this case, delayed toxicity has been observed in other reports, which happened 1 to 2 years after monotherapy $(26,27)$. Generally, other irAEs have been shown to be associated with the efficacy of PD-1/PD-L1 inhibitors in patients with lung cancer $(28,29)$. Same as other irAEs, grade 1 thrombocytopenia during ICIs therapy is positively associated with Overall survival (OS), but lacks of Progression-free survival (PFS) benefit (30). Immune thrombocytopenia usually is not fatal, but deaths caused by the adverse events had been reported in uncommon cases (25). Thus, ICIs-induced thrombocytopenia is potentially life-threatening and should be paid close attention in clinical practice.

\section{MECHANISM OF ICIS-INDUCED THROMBOCYTOPENIA}

Although the mechanism of drug-induced thrombocytopenia has been well demonstrated, the underlying mechanism of ICIs-induced thrombocytopenia remains unclear (31). Reinvigoration of exhausted $\mathrm{CD}^{+}$helper $\mathrm{T}$ cells and $\mathrm{CD}^{+}$cytotoxic $\mathrm{T}$ cells activates inflammatory pathways and ultimately results in damage to hematopoietic stem cells. In addition, ICI-induced antiplatelet antibody production can promote platelet destruction, which is supported by high antiplatelet antibody levels in patients who suffered from ICIs-induced thrombocytopenia $(7,18)$. Furthermore, the expression of PD-L1 on platelets in lung cancer patients was significantly increased, which might render susceptible targets of antibody-based anti-PD-L1 therapies. As a result, the amount of PD-L1-expressing platelets dramatically decreased in the blood of patients receiving PD-L1 therapy (32). Another suggested mechanism was activation of T-cells, leading to the secretion of different cytokines from T-helper cells (33). In the present case, although the patient has a high level of plateletassociated immunoglobulin $\mathrm{G}$ antibody and other possible causes of thrombocytopenia, particularly a viral infection, were excluded and multiple treatments were used including steroid, platelet transfusion, IVIG, and mycophenolate mofetil, the platelet counts recovered slightly. Importantly, the serum level of IL-6 was significantly higher than that of the normal range, indicating that the potential mechanism of ICIs-induced thrombocytopenia was relying on the abnormal cytokine secretion of activated lymphocytes. Consequently, the IL-6 receptor antagonist tocilizumab has achieved a partial response. 
TABLE 1 | Summary of reported lung cancer cases with immune thrombocytopenia after receiving ICls.

\begin{tabular}{|c|c|c|c|c|c|c|c|c|c|c|c|c|}
\hline Authors & Year & $\begin{array}{c}\text { Tumor } \\
\text { type }\end{array}$ & $\begin{array}{l}\text { PD1/ } \\
\text { PD- } \\
\text { L1 }\end{array}$ & ICls & $\begin{array}{c}\text { Treatment } \\
\text { lines }\end{array}$ & Radiotherapy & $\begin{array}{l}\text { Onset } \\
\text { times }\end{array}$ & $\begin{array}{c}\text { Lowest } \\
\text { PLT } \\
\left(\times 10^{3} / u l\right)\end{array}$ & Megakaryocyte & Treatment & $\begin{array}{l}\text { Efficacy } \\
\text { to ICls }\end{array}$ & Outcome \\
\hline $\begin{array}{l}\text { Present } \\
\text { case }\end{array}$ & 2020 & LAC & $\begin{array}{l}\text { PD- } \\
\text { L1 }\end{array}$ & Atezolizumab & First & None & $\begin{array}{l}875 \\
\text { days }\end{array}$ & 16 & Normal & $\begin{array}{l}\text { Steroids, TPO, } \\
\text { platelet } \\
\text { transfusions, } \\
\text { MMF, } \\
\text { tocilizumab }\end{array}$ & PR & Recovered \\
\hline Ito et al. (6) & 2020 & $\mathrm{LAC}$ & PD-1 & Pembrolizumab & Second & None & $\begin{array}{c}11 \\
\text { days }\end{array}$ & 0 & Increased & $\begin{array}{l}\text { Steroid, } \\
\text { platelet } \\
\text { transfusions, } \\
\text { TRA, IVIG, } \\
\text { rituximab }\end{array}$ & NA & Recovered \\
\hline $\begin{array}{l}\text { Mori et al. } \\
\text { (7) }\end{array}$ & 2019 & NSCLC & PD-1 & Nivolumab & Second & None & $\begin{array}{c}15 \\
\text { days }\end{array}$ & 2 & Maintained & $\begin{array}{l}\text { Steroids, } \\
\text { platelet } \\
\text { transfusions }\end{array}$ & PR & Recovered \\
\hline $\begin{array}{l}\text { Hasegawa } \\
\text { et al. (8) }\end{array}$ & 2019 & $\mathrm{LAC}$ & PD-1 & Nivolumab & Second & Yes & $\begin{array}{c}42 \\
\text { days }\end{array}$ & 2 & ND & $\begin{array}{l}\text { Steroids, } \\
\text { platelet } \\
\text { transfusions, } \\
\text { IVIG, TRA }\end{array}$ & NR & Died \\
\hline $\begin{array}{l}\text { Liu et al. } \\
\text { (9) }\end{array}$ & 2019 & LAC & $\begin{array}{l}\text { PD- } \\
\text { L1 }\end{array}$ & Durvalumab & First & None & $\begin{array}{l}266 \\
\text { days }\end{array}$ & 12 & Normal & Steroid, IVIG & PR & Died \\
\hline $\begin{array}{l}\text { Mouri et al. } \\
\text { (10) }\end{array}$ & 2019 & LAC & PD-1 & Pembrolizumab & First & Yes & $\begin{array}{c}21 \\
\text { days }\end{array}$ & 0.3 & Elevated & Steroid & PR & Improvement \\
\hline $\begin{array}{l}\text { Dickey } \\
\text { et al. (11) }\end{array}$ & 2019 & LUSC & PD-1 & Pembrolizumab & First & None & $\begin{array}{l}100 \\
\text { days }\end{array}$ & 21 & ND & Steroid & PR & Recovered \\
\hline $\begin{array}{l}\text { Song et al. } \\
(12)\end{array}$ & 2019 & NSCLC & PD-1 & Pembrolizumab & First & None & $\begin{array}{l}157 \\
\text { days }\end{array}$ & 0 & Normal & $\begin{array}{l}\text { Steroid, IVIG, } \\
\text { platelet } \\
\text { transfusions, } \\
\text { TRA }\end{array}$ & PR & Improvement \\
\hline $\begin{array}{l}\text { Yılmaz } \\
\text { et al. (13) }\end{array}$ & 2019 & $\mathrm{LAC}$ & $\begin{array}{l}\text { PD- } \\
\text { L1 }\end{array}$ & Atezolizumab & Third & None & 7 days & 19 & ND & $\begin{array}{l}\text { Steroid, } \\
\text { platelet } \\
\text { transfusions, } \\
\text { IVIG }\end{array}$ & NA & Recovered \\
\hline $\begin{array}{l}\text { Suyama } \\
\text { et al. (14) }\end{array}$ & 2019 & LUSC & $\begin{array}{l}\text { PD- } \\
\text { L1 }\end{array}$ & Durvalumab & Third & Yes & $\begin{array}{c}28 \\
\text { days }\end{array}$ & 7 & Decreased & $\begin{array}{l}\text { Steroid, } \\
\text { platelet } \\
\text { transfusions }\end{array}$ & PD & Recovered \\
\hline $\begin{array}{l}\text { Tokumo } \\
\text { et al. (15) }\end{array}$ & 2018 & LAC & PD-1 & Nivolumab & Second & None & $\begin{array}{c}40 \\
\text { days }\end{array}$ & 19 & Absence & $\begin{array}{l}\text { Steroids, } \\
\text { platelet } \\
\text { transfusions, } \\
\text { IVIG }\end{array}$ & PR & Died \\
\hline $\begin{array}{l}\text { Zhou et al. } \\
\text { (16) }\end{array}$ & 2018 & LSCC & PD-1 & Nivolumab & Third & None & $\begin{array}{l}180 \\
\text { days }\end{array}$ & 0 & Decreased & $\begin{array}{l}\text { Steroid, } \\
\text { plasma } \\
\text { exchanges }\end{array}$ & SD & Recovered \\
\hline $\begin{array}{l}\text { Fu et al. } \\
(17)\end{array}$ & 2018 & $\mathrm{LAC}$ & PD-1 & Nivolumab & Third & Yes & $\begin{array}{l}255 \\
\text { days }\end{array}$ & 11 & Increased & $\begin{array}{l}\text { Steroid, } \\
\text { platelet } \\
\text { transfusions, } \\
\text { TPO, IVIG }\end{array}$ & NA & Improvement \\
\hline $\begin{array}{l}\text { Jotatsu } \\
\text { et al. (18) }\end{array}$ & 2017 & LAC & PD-1 & Nivolumab & Third & None & $\begin{array}{c}29 \\
\text { days }\end{array}$ & 16 & Increased & Steroid & PR & Recovered \\
\hline $\begin{array}{l}\text { Karakas } \\
\text { et al. (19) }\end{array}$ & 2016 & NSCLC & PD-1 & Nivolumab & Second & None & $\begin{array}{c}85 \\
\text { days }\end{array}$ & 5 & Increased & $\begin{array}{l}\text { Steroid, } \\
\text { platelet } \\
\text { transfusions }\end{array}$ & NA & Died \\
\hline $\begin{array}{l}\text { Bagley } \\
\text { et al. (20) }\end{array}$ & 2016 & LUSC & PD-1 & Nivolumab & Second & Yes & $\begin{array}{c}99 \\
\text { days }\end{array}$ & 33 & NR & TRA & PR & Recovered \\
\hline
\end{tabular}

LAC, lung adenocarcinoma; NSCLC, non-small-cell lung cancer; LSCC, lung squamous cell carcinoma; LUSC, lung squamous cell carcinoma; ICl, immune checkpoint inhibitor; MMF, mycophenolate mofetil; IVIG, intravenous immunoglobulin; TRA, thrombopoietin receptor agonist; TPO, thrombopoietin; PR, partial response; CR, complete response; SD, stable disease; $P D$, progressive disease; NA, not available.

\section{DIAGNOSIS AND TREATMENT}

ICIs-induced thrombocytopenia mimics virtually any other type of thrombocytopenia, making it a diagnosis of exclusion and is difficult due to the lack of specific testing. Any new platelet count decrease should be considered as immune thrombocytopenia for patients receiving ICIs therapy. Generally, bone marrow examination is necessary to exclude dysplasia or cancer invasion. In addition, other examinations should be administrated to distinguish ICIs-induced thrombocytopenia from other etiologic agents, such as drug- 
induced thrombocytopenia (heparin/HITT, chemotherapy, etc.), infections, hematological malignancies (myelodysplastic syndrome, etc.), platelet sequestration (spleen, liver diseases), platelet consumption (thrombotic thrombocytopenic purpura, etc.) $(9,34,35)$. Furthermore, the presence of a high plateletassociated IgG titer may be helpful to diagnose ICIs-induced thrombocytopenia (14). Therefore, effective recognition and diagnosis for immune thrombocytopenia are important because of the different prognosis and therapeutic management. In our case, absence of liver, spleen, or rheumatologic disease; malignant infiltration of the bone marrow; and other causes of thrombocytopenia suggest that thrombocytopenia was induced by atezolizumab. Sometimes, the lack of efficacy of transfusions during and after ICI administration is indicative of ICIsinduced thrombocytopenia.

The targeted therapies are not well defined for immune thrombocytopenia induced by ICIs. According to the American Society of Clinical Oncology (ASCO) guidelines, grading treatment on severity classification is the current principle for immune thrombocytopenia (36). Generally, the management of grade 1 toxicities $\left(<100 \times 10^{3} / \mathrm{ul}\right)$ should comply with the clinical and laboratory evaluation. Sometimes ICIs need not stop, and platelet changes should be continued with close monitoring. Withholding ICIs therapy is generally recommended for grade 2 toxicities $\left(<75 \times 10^{3} / \mathrm{ul}\right)$ until the platelets recover to grade 1 toxicities, and oral corticosteroids $(0.4-1 \mathrm{mg} / \mathrm{kg} /$ day of prednisone or equivalent) should be presented with 2-4 weeks and/or conjunctive use of IVIG. But the dose adjustment is not advised if ICIs therapy is readministrated because irAEs are not dose-dependent (37). For grade 3 toxicities $\left(<50 \times 10^{3} / \mathrm{ul}\right)$ or grade 4 toxicities $\left(<25 \times 10^{3} / \mathrm{ul}\right)$, ICIs therapy must be definitively discontinued until return to grade 1 toxicities, with the administration of high-dose corticosteroids and optional IVIG, with permanent ICIs, withdrawal is necessary if platelet do not resolute to normal. Other therapy strategies include recombinant human TPO, romiplostim, platelet transfusion, and immunosuppressive agents, such as azathioprine and rituximab. Steroids are generally essential for treating immune thrombocytopenia by ICIs but are not always effective in severe thrombocytopenia. Many studies have demonstrated that the

\section{REFERENCES}

1. Abdayem P, Planchard D. Safety of Current Immune Checkpoint Inhibitors in Non-Small Cell Lung Cancer. Expert Opin Drug Saf (2021) 20(6):651-67. doi: 10.1080/14740338.2021.1867100

2. Mansfield AS, Każarnowicz A, Karaseva N, Sánchez A, De Boer R, Andric Z, et al. Safety and Patient-Reported Outcomes of Atezolizumab, Carboplatin, and Etoposide in Extensive-Stage Small-Cell Lung Cancer (Impower133): A Randomized Phase I/Iii Trial. Ann Oncol (2020) 31(2):310-7. doi: 10.1016/ j.annonc.2019.10.021

3. Gergi M, Landry KK, Ades S, Barry M, Zakai NA, Herrera DA. NivolumabInduced Thrombotic Thrombocytopenic Purpura in a Patient With Anal Squamous Cell Carcinoma: A Lesson on Hematologic Toxicity From Immunotherapy. Oncologist (2020) 25(12):1009-12. doi: 10.1002/ onco. 13553

4. Hantel A, Gabster B, Cheng JX, Golomb H, Gajewski TF. Severe Hemophagocytic Lymphohistiocytosis in a Melanoma Patient Treated With presence of specific single-nucleotide polymorphisms, such as PD-1 -606 AA genotype and +63379 TT genotype, affects the susceptibility to prednisolone treatment (38). In addition, HLA$\mathrm{DRB}^{\star} 0410$ or HLA-DRB $1^{\star} 0405$ allele in the patients' immune thrombocytopenia has been reported to contribute to steroid therapy resistance $(20,39)$. This can explain why the patient had a weak response to steroid therapy.

\section{CONCLUSION}

Although ICIs-induced thrombocytopenia is rare in patients receiving ICIs, we still need to pay more attention to this issue because of its life-threatening characteristic. Any new abnormality of platelet counts should be considered as a potential clinical significance for immunotherapy patients; thus, careful recognition and accurate diagnosis are extremely important. Although its response to steroids, IVIG, and platelet transfusion is relatively good, the underlying mechanism of immune thrombocytopenia remains elusive, and further study is awaited.

\section{AUTHOR CONTRIBUTIONS}

LC developed the idea for the study. WX and NH did data collection, data analysis, and manuscript preparation. All authors have reviewed and approved the final version of the manuscript and have consented to its publication.

\section{FUNDING}

This work was supported by the National Natural Science Foundation of China (82000082), Natural Science Foundation of Anhui Province (2008085QH353), and the Fundamental Research Funds for the Central University (WK9110000124).
Ipilimumab + Nivolumab. J Immunother Cancer (2018) 6(1):73. doi: 10.1186/ s40425-018-0384-0

5. Bai S, Tian T, Pacheco JM, Tachihara M, Hu P, Zhang J. Immune-Related Adverse Event Profile of Combination Treatment of Pd-(L)1 Checkpoint Inhibitors and Bevacizumab in Non-Small Cell Lung Cancer Patients: Data From the Fda Adverse Event Reporting System. Transl Lung Cancer Res (2021) 10(6):2614-24. doi: 10.21037/tlcr-21-464

6. Ito M, Kanda S, Yoshida T, Okuma Y, Jo H, Fukuhara S, et al. Eltrombopag Olamine for Refractory Immune-Related Thrombocytopenia Induced by Pembrolizumab in a Non-Small Cell Lung Cancer Patient. Lung Cancer (2020) 146:362-5. doi: 10.1016/j.lungcan.2020.05.015

7. Mori H, Sakai C, Iwai M, Sasaki Y, Gomyo T, Toyoshi S, et al. Immune Thrombocytopenia Induced by Nivolumab in a Patient With Non-Small Cell Lung Cancer. Respir Med Case Rep (2019) 28:100871. doi: 10.1016/ j.rmcr.2019.100871

8. Hasegawa T, Ozaki Y, Inoue T, Watanabe Y, Fukuhara M, Yamaura T, et al. Nivolumab-Related Severe Thrombocytopenia in a Patient With Relapsed 
Lung Adenocarcinoma: A Case Report and Review of the Literature. J Med Case Rep (2019) 13(1):316. doi: 10.1186/s13256-019-2245-y

9. Liu X, Liang X, Liang J, Li Y, Wang J. Immune Thrombocytopenia Induced by Immune Checkpoint Inhibitors in Solid Cancer: Case Report and Literature Review. Front Oncol (2020) 10:530478. doi: 10.3389/fonc.2020.530478

10. Mouri A, Kaira K, Shiono A, Miura YU, Kagamu H. Severe Thrombocytopenia Associated With Pembrolizumab in Patients With Non-Small Cell Lung Cancer (Nsclc): A Case Report and Literature Review. In Vivo (2020) 34(2):877-80. doi: 10.21873/invivo.11852

11. Dickey MS, Raina AJ, Gilbar PJ, Wisniowski BL, Collins JT, Karki B, et al. Pembrolizumab-Induced Thrombotic Thrombocytopenic Purpura. J Oncol Pharm Pract (2020) 26(5):1237-40. doi: 10.1177/1078155219887212

12. Song P, Zhang L. Eltrombopag Treatment for Severe Refractory Thrombocytopenia Caused by Pembrolizumab. Eur J Cancer (2019) 121:46. doi: 10.1016/j.ejca.2019.08.003

13. Yılmaz A, Mirili C, Bilici M, Tekin SB. Possible Atezolizumab-Associated Acute Kidney Injury and Immune Thrombocytopenia. J Oncol Pharm Pract (2020) 26(7):1791-4. doi: 10.1177/1078155220913081

14. Suyama T, Hagihara M, Kubota N, Osamura Y, Shinka Y, Miyao N. Acquired Amegakaryocytic Thrombocytopenia After Durvalumab Administration. J Clin Exp Hematop (2021) 61(1):53-7. doi: 10.3960/jslrt.20047

15. Tokumo K, Masuda T, Miyama T, Miura S, Yamaguchi K, Sakamoto S, et al. Nivolumab-Induced Severe Pancytopenia in a Patient With Lung Adenocarcinoma. Lung Cancer (2018) 119:12-5. doi: 10.1016/j.lungcan.2018.02.018

16. Zhou H, Li N, Tang H, Chen H, Chen X, Zhang L, et al. Delayed Thrombocytopenia as a Rare But Serious Adverse Event Secondary to Immune Checkpoint Inhibitor: A Case Report. Ann Palliat Med (2021) 10 (5):5881-6. doi: 10.21037/apm-21-794

17. Fu S, Wang T, Xu F. Delayed Immune Thrombocytopenia After Discontinuation of Nivolumab Therapy: A Case Report and Literature Review.JOncol Pharm Pract (2021) 27(6):1548-52. doi: 10.1177/1078155220981155

18. Jotatsu T, Oda K, Yamaguchi Y, Noguchi S, Kawanami T, Kido T, et al. Immune-Mediated Thrombocytopenia and Hypothyroidism in a Lung Cancer Patient Treated With Nivolumab. Immunotherapy-Uk (2018) 10 (2):85-91. doi: 10.2217/imt-2017-0100

19. Karakas Y, Yuce D, Kllickap S. Immune Thrombocytopenia Induced by Nivolumab in a Metastatic Non-Small Cell Lung Cancer Patient. Oncol Res Treat (2017) 40(10):621-2. doi: 10.1159/000477968

20. Bagley SJ, Kosteva JA, Evans TL, Langer CJ. Immune Thrombocytopenia Exacerbated by Nivolumab in a Patient With Non-Small-Cell Lung Cancer. Cancer Treat Commun (2016) 6:20-3. doi: 10.1016/j.ctrc.2016.02.009

21. Rogers BB, Zawislak C, Wong V. Management of Hematologic Adverse Events Associated With Immune Checkpoint Inhibitors. J Adv Pract Oncol (2021) 12(4):392-404. doi: 10.6004/jadpro.2021.12.4.4

22. Shiuan E, Beckermann KE, Ozgun A, Kelly C, McKean M, McQuade J, et al. Thrombocytopenia in Patients With Melanoma Receiving Immune Checkpoint Inhibitor Therapy. J Immunother Cancer (2017) 5:8. doi: 10.1186/s40425-0170210-0

23. Delanoy N, Michot JM, Comont T, Kramkimel N, Lazarovici J, Dupont R, et al. Haematological Immune-Related Adverse Events Induced by Anti-Pd-1 or Anti-Pd-L1 Immunotherapy: A Descriptive Observational Study. Lancet Haematol (2019) 6(1):e48-57. doi: 10.1016/S2352-3026(18)30175-3

24. Michot JM, Lazarovici J, Tieu A, Champiat S, Voisin AL, Ebbo M, et al. Haematological Immune-Related Adverse Events With Immune Checkpoint Inhibitors, How to Manage? Eur J Cancer (2019) 122:72-90. doi: 10.1016/ j.ejca.2019.07.014

25. Davis EJ, Salem JE, Young A, Green JR, Ferrell PB, Ancell KK, et al. Hematologic Complications of Immune Checkpoint Inhibitors. Oncologist (2019) 24(5):584-8. doi: 10.1634/theoncologist.2018-0574

26. Berger M, Amini-Adlé M, Crumbach L, Paubelle E, Dalle S. A Case of Immune Thrombocytopaenia Induced by Pembrolizumab in a Metastatic Melanoma Patient With a History of Immune-Mediated Pure Red Cell Aplasia. Eur J Cancer (2019) 112:94-7. doi: 10.1016/j.ejca.2019.02.006

27. Bulbul A, Mustafa A, Chouial S, Rashad S. Idiopathic Thrombocytopenic Purpura and Autoimmune Neutropenia Induced by Prolonged Use of
Nivolumab in Hodgkin's Lymphoma. Ann Oncol (2017) 28(7):1675-6. doi: $10.1093 /$ annonc/mdx159

28. Cortellini A, Chiari R, Ricciuti B, Metro G, Perrone F, Tiseo M, et al. Correlations Between the Immune-Related Adverse Events Spectrum and Efficacy of Anti-Pd1 Immunotherapy in Nsclc Patients. Clin Lung Cancer (2019) 20(4):237-47. doi: 10.1016/j.cllc.2019.02.006

29. Ezponda CA, Calvo IM, de Torres TJ, García-Baizán A, Castañón ÁE, Cano $\mathrm{RD}$, et al. Immune-Related Adverse Events as Predictors of Response in Cancer Patients Undergoing Immunotherapy. Radiol (Engl Ed) (2020) 62 (2):131-8. doi: 10.1016/j.rx.2019.06.004

30. Assi HA, Asch AS, Machiorlatti M, Vesely SK, Ibrahimi S. Development of Thrombocytopenia Is Associated With Improved Survival in Patients Treated With Immunotherapy. Future Sci OA (2020) 6(7):O581. doi: 10.2144/fsoa2020-0021

31. Kopecký J, Trojanová P, Kubeček O, Kopecký O. Treatment Possibilities of Ipilimumab-Induced Thrombocytopenia-Case Study and Literature Review. Jpn J Clin Oncol (2015) 45(4):381-4. doi: 10.1093/jjco/hyu222

32. Rolfes V, Idel C, Pries R, Plötze-Martin K, Habermann J, Gemoll T, et al. Pd-L1 Is Expressed on Human Platelets and Is Affected by Immune Checkpoint Therapy. Oncotarget (2018) 9(44):27460-70. doi: 10.18632/ oncotarget. 25446

33. Quirk SK, Shure AK, Agrawal DK. Immune-Mediated Adverse Events of Anticytotoxic T Lymphocyte-Associated Antigen 4 Antibody Therapy in Metastatic Melanoma. Transl Res (2015) 166(5):412-24. doi: 10.1016/ j.trsl.2015.06.005

34. Amanam I, Gupta R, Pullarkat V, Mei M. Immune Thrombocytopenia After Immune Checkpoint Inhibitor Therapy. Br J Haematol (2021) 193(3):677-81. doi: $10.1111 /$ bjh.17387

35. Calvo R. Hematological Side Effects of Immune Checkpoint Inhibitors: The Example of Immune-Related Thrombocytopenia. Front Pharmacol (2019) 10:454. doi: 10.3389/fphar.2019.00454

36. Brahmer JR, Lacchetti C, Schneider BJ, Atkins MB, Brassil KJ, Caterino JM, et al. Management of Immune-Related Adverse Events in Patients Treated With Immune Checkpoint Inhibitor Therapy: American Society of Clinical Oncology Clinical Practice Guideline. J Clin Oncol (2018) 36(17):1714-68. doi: 10.1200/JCO.2017.77.6385

37. Weber JS, Kähler KC, Hauschild A. Management of Immune-Related Adverse Events and Kinetics of Response With Ipilimumab. J Clin Oncol (2012) 30 (21):2691-7. doi: 10.1200/JCO.2012.41.6750

38. Kasamatsu T, Ino R, Takahashi N, Gotoh N, Minato Y, Takizawa M, et al. Pdcd1 and Ctla4 Polymorphisms Affect the Susceptibility to, and Clinical Features of, Chronic Immune Thrombocytopenia. Br J Haematol (2018) 180 (5):705-14. doi: 10.1111/bjh.15085

39. Nomura S, Matsuzaki T, Ozaki Y, Yamaoka M, Yoshimura C, Katsura K, et al. Clinical Significance of Hla-Drb ${ }^{*} 0410$ in Japanese Patients With Idiopathic Thrombocytopenic Purpura. Blood (1998) 91(10):3616-22. doi: 10.1182/ blood.V91.10.3616

Conflict of Interest: The authors declare that the research was conducted in the absence of any commercial or financial relationships that could be construed as a potential conflict of interest.

Publisher's Note: All claims expressed in this article are solely those of the authors and do not necessarily represent those of their affiliated organizations, or those of the publisher, the editors and the reviewers. Any product that may be evaluated in this article, or claim that may be made by its manufacturer, is not guaranteed or endorsed by the publisher.

Copyright $\odot 2021 \mathrm{Xie}, \mathrm{Hu}$ and Cao. This is an open-access article distributed under the terms of the Creative Commons Attribution License (CC BY). The use, distribution or reproduction in other forums is permitted, provided the original author(s) and the copyright owner(s) are credited and that the original publication in this journal is cited, in accordance with accepted academic practice. No use, distribution or reproduction is permitted which does not comply with these terms. 